\title{
PENGARUH FAKTOR POLEKSOSBUD TERHADAP PENDIDIKAN DAN PERANAN PENDIDIKAN DALAM MEMBANGUN POLEKSOSBUD
}

\author{
Henry Eryanto \\ Dosen Fakultas Ekonomi Universitas Negeri Jakarta
}

\begin{abstract}
ABSTRAK
Kekuatan suatu bangsa khususnya dalam proses pembangunan nasional tergantung kepada tingkat pendidikan masyarakatnya. Jadi sangat jelas bagi kita semua bahwa betapa pentingnya pendidikan bagi suatu bangsa di dunia ini, baik bangsa yang berasal dari masyarakat yang homogen maupun bangsa yang berasal dari masyarakat heterogen, multikultur dengan tingkat keragaman yang begitu tinggi seperti Indonesia. Bangsa Indonesia sebagai bangsa yang memiliki karakter dengan perbedaan yang sangat beragam dibangun dengan menciptakan semangat persatuan yang kokoh dan toleransi yang tinggi. Pembangunan peradaban bangsa harus didasari dengan pembangunan nilai-nilai moral di kalangan warga bangsa baik sebagai individu maupun kelompok. Nilai-nilai moral yang kokoh dan etika standar yang kuat amat diperlukan bagi warga bangsa untuk menghadapi tantangan-tantangan masa depan. Nilai-nilai moral suatu bangsa amat berkaitan erat dengan kekuatan bangsa itu sendiri.Melalui suatu sistem pendidikan nasional tumbuhlah semangat persatuan yang menjiwai keanekaragaman etnis, agama, budaya, sosial bahkan politik. Sistem pendidikan nasional yang dibangun dengan memahami keragaman menjadi sumber kekuatan untuk melebur perbedaan-perbedaan sehingga dapat diwujudkan rasa kebangsaan yang kokoh.
\end{abstract}

Kata Kunci: sistem pendidikan nasional, pembangunan nasional

\section{PENDAHULUAN}

Pendidikan

diharapkan mampu melahirkan manusia Indonesia yang: 1) religius dan bermoral, 2) yang menguasai ilmu pengetahuan dan keterampilan, 3) sehat jasmani dan rohani dan 4) berkepribadian dan bertanggung jawab (Soedijarto, 2008:118). Dengan demikian pendidikan harus mewujudkan keempat karakteristik tersebut sebagai tujuan umum dari pendidikan nasional kita. Dengan mewujudkan keempat karakteristik 
tersebut berarti pendidikan akan membangun suatu peradaban bangsa dan negara Indonesia.

Pembangunan peradaban bangsa harus didasari dengan pembangunan nilai-nilai moral di kalangan warga bangsa baik sebagai individu maupun kelompok. Nilai-nilai moral yang kokoh dan etika standar yang kuat amat diperlukan bagi warga bangsa untuk menghadapi tantangan-tantangan masa depan. Nilai-nilai moral suatu bangsa amat berkaitan erat dengan kekuatan bangsa itu sendiri. Sebab, nilai-nilai moral inilah yang menggerakkan warga bangsa tersebut. Oleh karena itu, semakin kokoh nilai-nilai yang dipegang warga bangsa akan melahirkan social capital, jaringan hubungan, dan norma-norma perilaku yang mengikat suatu warga bangsa yang menjiwai kehidupan bersama, dalam wujud keberadaan trust di antara sesama warga masyarakat (Zamroni dalam Tilaar, 2003: 33).

Kehadiran trust ini akan menimbulkan hubungan yang saling mempercayai dalamsegala aspek kehidupan. Hasilnya, kehidupan politik akan lebih santun, hubungan ekonomi akan lebih lancar, kehidupan sosial akan dijiwai dengan kebersamaan dan saling memperhatikan dan perkembangan budaya sesuai dengan nilai - nilai yang tumbuh dalam masyarakat Indonesia.

Indonesia baru yang dicitacitakan oleh seluruh rakyat Indonesia adalah masyarakat baru yang disebut civil society (Soedijarto. 2008). Hal ini berarti kekuasaan berada di tangan rakyat, ditentukan oleh rakyat, dan untuk rakyat.Rakyat tidak lagi menjadi objek, tetapi sebagai subjek pelaku kekuasaan. Masyarakat madani hanya dapat terwujud jika masyarakat memperoleh pendidikan yang memadai sehingga masyarakat dapat memahami perannya dalam proses perubahan sosial secara kreatif-konstruktif untuk mencari bentuk sintetik baru secara tulus, damai sekaligus mencerahkan. Oleh karena itu, pemerintah seharusnya dapat meningkatkan komitmennya untuk menciptakan pemerintahan yang bersih, menegakkan hukum tanpa pandang bulu, dan berpihak pada proses pemberdayaan rakyat dengan memprioritaskan bidang pendidikan. Kesejahteraan rakyat seharusnya diartikan dengan semakin meningkatnya kualitas SDM yang terdidik agar mampu meningkatkan penghasilannya secara benar, mandiri dan kreatif.Ukuran kesejahteraan rakyat harus menyertakan indikator menguatnya etika sosial, kualitas 
partisipasi rakyat dalam politik, kreativitas budaya dan komitmen moralitas keagamaan dan kemanusiaan universal, tidak semata-mata menggunakan indikator ekonomi.

Terkait dengan politik, ada anggapan negatif, skeptik dan sinis warga sehingga ada kecenderungan menghindari politik. Namun perlu dicatat beberapa hal: pertama, kita tidak dapat lepas dari politik, semua kegiatan mengandaikan kerangka negara dan masyarakat merupakan aktivitas politik. Kedua, berbagai kesulitan yang dihadapi seperti peningkatan kesejahteraan, lingkungan hidup, kesenjangan sosial-ekonomi, pendidikan dan pengembangan IPTEK tidak dapat dipecahkan tanpa politik, tetapi dengan transformasi politik sedemikian rupa sehingga memungkinkan membentuk dan mengorganisir kehidupan secara efektif. Ketiga, sikap sinis dan skeptik terhadap politik dapat dihindari dengan membangun kredibilitas, kelayakan model alternatif dan imaginatif institusi politik.

Oleh karena itu, pendidikan merupakan sektor yang dapat mempengaruhi seluruh aspek kehidupan berbangsa mulai dari aspek politik. Melalui pendidikan (politik) diharapkan para pelaku politik bisa lebih memahami posisi sekaligus tugas dan tanggung jawab yang diemban bagi kesejahteraan rakyat, dalam kondisi politik yang dinamis dan mendukung.Sehingga setiap orang yang berkecimpung di dunia politik menyadari hakikat berpolitik, dengan mengembangkan budaya dan etika politik yang bersih dan profesional. Pendidikan yang dimaksud meliputi segala aspek yang dapat memberikan pemahaman baru mengenai apa, untuk apa, bagi siapa sesuatu (kekuasaan) harus dicapai dan di pertahankan. Kemudian aspek ekonomi, dengan Pendidikan diharapkan dapat menunjang proses kehidupan ekonomi bahkan dapat mempengaruhi arah dari proses pengembangan ekonomi karena pelaku-pelaku kehidupan ekonomi adalah manusia itu sendiri. Selanjutnya, perkembangan ekonomi pada gilirannya akan menunjang terwujudnya proses pendidikan yang dibutuhkan dalam perkembangan ekonomi. Ekonomi baru adalah ekonomi yang berdasarkan ilmu pengetahuan. Oleh karenanya, proses pendidikan harus menekankan keseimbangan antara nilai-nilai moral dan etika dengan nilai-nilai ekonomi, karena antara nilai-nilai moral, etika, dan nilai-nilai ekonomi mempunyai hubungan timbal balik. Selanjutnya 
aspek sosial budaya, keragaman Indonesia baik suku, agama dan budaya adalah suatu rakhmat dari Allah yang Maha Kuasa, memang untuk membangun sebuah peradaban bangsa yang baik dan kuat dari keanekaragaman ini bukanlah suatu pekerjaan sederhana yang dapat dilakukan dalam kurun waktu yang singkat. Karena, kekuatan-kekuatan eksternal dan tantangan globalisasi pasti akan berusaha menghambat tatanan masyarakat yang sedang dibangun tersebut. Tetapi melaluisuatu Sistem Pendidikan Nasional keragaman ini diharapkan dapat dipadukan membentuk suatu masyarakat yang berkarakter dengan kekayaan budaya yang beraneka ragam.

\section{A. Pendidikan dan Politik}

\section{Kondisi Politik "Pendidikan"}

Banyak pihak yang melihat pendidikan sebagai faktor dan kekuatan politik (Kartini Kartono. 1990). Karena, pendidikan dan sekolah merupakan pencerminan dari kekuatan sosial politik yang tengah berkuasa, dan refleksi dari orde penguasa yang ada.Di samping itu pendidikan berlangsung dalam konteks politik dengan pengembangan sistem pendidikan yang dimasukkan ke dalam kerangka kebulatan kehidupan bangsa, ketahanan nasional dan politik NKRI.Lebih jauh lagi menyangkut policy, perencanaan, atribut edukasi, pelaksanaan, tujuan pendidikan, relasi struktural dengan lembaga non-edulatif lain, pembiayaan dan manajemen pendidikan, semuanya diputuskan berdasarkan konsensus dan keputusan politik pemerintah yang bersifat non-edukatif.Contoh konkritnya adalah tujuanpendidikan yang intinya merupakan penjabaran dari filsafat negara dan tujuan politik negara RI yang hakekatnya merupakan realisasi keinginan dan keputusan para pemimpin yang berkuasa.

Kondisi politik Indonesia dewasa ini dinilai masih dalam tataran belajar, terlebih bila dikaitkan dengan dunia pendidikan. Di satu sisi dunia pendidikan dikatakan sebagai faktor dan kekuatan politik, namun di sisi lain pelaku pendidikan dipatok untuk tidak terlibat dalam politik praktis. Sehingga, dengan demikian pendidik dan dunia pendidikan secara umum cenderung dijadikan objek politisasi.Sementara masih banyak Warga Negara yang belum memahami politik hal in dikarenakan mereka belum memperoleh pendidikan politik dengan baik, padahal mereka perlu belajar dan sekaligus memahami berbagai 
persoalan yang dihadapi bangsa dan negerinya. Kenyataannya dalam usia 64 tahun kemerdekaan Indonesia, dunia pendidikan masih terpasung kepentingan politik praktis dan ambiguitas kekuasaan. Padahal, politik dan kekuasaan suatu negara memegang kunci keberhasilan pendidikan.Dalam konteks pembangunan demokratisasi dan desentralisasi di Indonesia, peran politik eksekutif dan legislatif untuk memajukan pendidikan begitu besar.Ranah politik dan kekuasaan harus mampu mewujudkan sistem pendidikan yang mencerdaskan dan mencerahkan peradaban bangsa ini.

Paulo Freire (1970) pernah menegaskan bahwa bagaimanapun kebijakan politik sangat menentukan arah pembinaan dan pembangunan pendidikan. Freire memandang politik pendidikan memiliki nilai penting untuk menentukan kinerja pendidikan suatu negara. Bangsa yang politik pendidikannya buruk, maka kinerja pendidikannya pun pasti buruk. Sebaliknya, negara yang politik pendidikannya bagus, kinerja pendidikannya pun juga akan bagus.

Sampai saat ini, realitas politik pendidikan Indonesia masih belum sepenuhnya merdeka. Hal ini bisa dilihat dari komitmen pemerintah yang masih rendah dalam mewujudkan akses dan pemerataan pendidikan dasar yang bebas biaya, belum terpenuhinya anggaran pendidikan sebesar $20 \%$, kurangnya penghargaan terhadap profesionalisme dan kesejahteraan guru, rendahnya mutu dan daya saing pendidikan, upaya otonomi pendidikan yang masih setengah hati, dan sebagainya. Padahal pemerintah sebetulnya telah menetapkan Renstra Pendidikan tahun 2010-2014 dengan tiga sasaran pembangunan pendidikan nasional yang akan dicapai, yaitu meningkatkan perluasan dan pemerataan pendidikan, meningkatkan mutu dan relevansi pendidikan dan meningkatkan tata kepemerintahan (governance), akuntabilitas, dan pencitraan publik.

Pada saat yang sama, kesenjangan partisipasi pendidikan juga masih terjadi, terutama antara penduduk miskin dan penduduk kaya. Meski pemerintah telah menyediakan dana BOS, masih ditemukan beberapa sekolah yang masih menarik berbagai iuran, sehingga memberatkan orang tua, terutama bagi keluarga miskin. Kesenjangan partisipasi pendidikan tersebut terlihat makin mencolok pada jenjang pendidikan menengah dan pendidikan tinggi. Data 2008 menunjukkan bahwa APM SD/MI 
mencapai 95\%, SMP/MTs sebesar $71,83 \%$. Sementara itu, APK SMA/MA/SMK sebesar $55,22 \%$, dan APK pendidikan tinggi hanya mencapai 16,70\%. Sedangkan angka putus sekolah tingkat SD mencapai 2,97\%, SMP 2,42\%, SMA 3,06\%, dan PT 5,9\%. Kondisi ini diperparah dengan masih tingginya jumlah warga negara yang buta huruf, tercatat bahwa dari total penduduk sebanyak 211.063.000 jiwa, yang masih buta huruf pada usia 15 tahun ke atas berjumlah 15.4 juta, dengan perbandingan laki-laki $5,8 \%$ dan perempuan $12,3 \%$, dengan penyebaran di perkotaan 4,9\%, dan pedesaan $12,2 \%$ (Anwar Arifin)

Keadaan tersebut memberi gambaran mengenai realitas politik pendidikan di Indonesia yang belum merdeka dan tertinggal dari tuntutan daya saing global. Politik pendidikan kita belum mampu memberikan harapan konkrit atas kemajuan bangsa di masa depan. Karenanya perlu dilakukan penilaian ulang, revisi, pembaharuan dan penyempurnaan sistem pendidikan nasional, agar pendidikan lebih relevan dan lebih fungsional dengan tuntutan zaman. Untuk itu diperlukan good will politik, kebijakan dan praktek politik oleh pemerintah untuk mendukung pelaksanaannya. Dan akhirnya untuk menjabarkan filsafat Pancasila, filsafat pendidikan dan pelaksanaan pendidikan nasional ke dalam perilaku sosial dan perilaku edukatif yang sesuai dengan ketentuan yang ditetapkan pemerintah, jelas diperlukan kemauan politik, keputusan politik dan perbuatan politik secara konkrit. Untuk melaksanakan hal tersebut dibutuhkan politisi yang memahami urgensi politik bagi pendidikan dan politisi handal ini hanya mungkin didapat dari mereka yang pernah mengenyam pendidikan politik secara maksimal.

\section{Pendidikan Politik}

Pendidikan Politik, merupakan salah satu fungsi input sistem politik yang berlaku di negara manapun juga baik yang menganut sistem politik demokratis, otoriter, diktator dan sebagainya. Pendidikan politik, merupakan proses pembentukan sikap dan orientasi politik pada warganegara dimana keterlaksanaannya sangat ditentukan oleh lingkungan sosial, ekonomi dan kebudayaan di mana individu berada, selain itu, juga ditentukan oleh interaksi pengalaman serta kepribadian seseorang. Disisi lain kegiatan ini juga dipandang sebagai proses yang berlangsung lama dan rumit yang dihasilkan dari usaha saling 
mempengaruhi di antara kepribadian individu dengan pengalaman politik yang relevan yang memberi bentuk terhadap tingkah laku politiknya. Pengetahuan, nilai dan sikap yang diperoleh seseorang itu membentuk satu layar persepsi, melalui mana individu menerima rangsangan politik yang akan menentukan bentuk etika politik seseorang yang berkembang berangsur-angsur.

Jadi, pendidikan politik adalah proses dengan mana individu dapat memperoleh pengetahuan, nilai dan sikap terhadap sistem politik masyarakat (Kartini Kartono, 1989). Namun, peristiwa ini tidak menjamin bahwa masyarakat mengesahkan sistem politiknya, sekalipun hal ini mungkin bisa terjadi, sebab bisa saja menyebabkan pengingkaran terhadap legitimasi. Tetapi, apakah akan menuju kepada stagnasi atau perubahan, tergantung keadaan yang menyebabkan pengingkaran. Apabila tidak ada legitimasi disertai dengan sikap bermusuhan yang aktif terhadap sistem politik, maka perubahan mungkin terjadi.Sebaliknya, jika legitimasi dibarengi dengan sikap apatis terhadap sistem politik, bukan tak mungkin menghasilkan stagnasi. Dengan demikian keberadaan pendidikan politik menjadi sangat urgen, karena (1) secara fundamental merupakan proses hasil belajar; (2) memberikan indikasi hasil belajar tingkah laku individu dan kelompok yang berkenaan dengan pengetahuan, informasi, nilai dan sikap; (3) dapat dilakukan sepanjang hidup; dan (4) merupakan prakondisi yang diperlukan bagi aktivitas sosial yang secara implisit dan eksplisit memberikan penjelasan tingkah laku social (Kartini Kartono, 1989).

Perkembangan sosiologi politik pada dasarnya diawali pada masa kanak-kanak. Di AS, belajar politik dimulai usia 3 tahun dan menjadi mantap pada usia 7 tahun (Mariam Budiarjo, 1997). Tahap lebih awal dari belajar politik mencakup perkembangan dari ikatan lingkungan, seperti keterikatan pada sekolah dan berdiam di daerah tertentu, dengan demikian diharapkan mereka mempunyai kepercayaan pada keindahan negerinya, kebaikan serta kebersihan rakyatnya.Manifestasi ini diikuti oleh simbol otoritas umum, seperti polisi, presiden dan bendera nasional. Usia 9 dan 10 tahun timbul kesadaran akan konsep yang lebih abstrak, seperti pemberian suara, demokrasi, kebebasan sipil dan peran warganegara dalam sistem politik. Untuk mewujudkan pendidikan politik tersebut sedikitnya terdapat empat tahap 
yaitu (1) pengenalan otoritas melalui individu tertentu, seperti orang tua anak, presiden dan polisi; (2) perkembangan pembedaan antara otoritas internal dan ekternal, yaitu antara pejabat swasta dan pejabat pemerintah; (3) pengenalan mengenai institusi politik yang impersonal, seperti kongres (parlemen), mahkamah agung, dan pemilu; dan (4) perkembangan pembedaan antara institusi politik dan mereka yang terlibat dalam aktivitas yang diasosiasikan dengan institusi ini (Mochtar Buchori, 2000).

Tahapan pendidikan politik tersebut dapat dilakukan melalui keluarga, sekolah dan partai politik (Tilaar., 2003). Masalahnya adalah sosiologi politik dalam masyarakat berkembang dan berubah dengan cepat.Sifat pendidikan politik yang bervariasi menurut waktu serta yangselalu menyesuaikan dengan lingkungan yang memberinya kontribusi, berkaitan dengan sifat pemerintahan dan derajat serta sifat perubahan.Semakin stabil pemerintahan, semakin terperinci agensi-agensi utama dari pendidikan politik.Sebaliknya, semakin besar derajat perubahan, semakin tersebarlah agensi utama dari pendidikan politik.

Dalam realitas kehidupan, pola pendidikan politik juga mengalami perubahan seperti berubahnya struktur dan kultur politik. Perubahan tersebut menyangkut perbedaan tingkat keterlibatan dan derajat perubahan dalam sub sistem masyarakat yang beraneka ragam. Sehingga dikatakan bahwa pendidikan politik bisa bersifat manifesdan laten. Pendidikan politik yang bersifat manifes berlangsung dalam bentuk transmisi informasi, nilai atau perasaan terhadap peran, input dan output mengenai sistem politik. Sedangkan, pendidikan politik laten berlangsungdalam bentuk transmisi informasi, nilai atau perasaan terhadap peran, input dan output mengenai sistem sosial yang lain seperti keluarga.

Membangun sebuah kultur demokratis dari pola pendidikan politik yang diterapkan dapat dilakukan dengan menggelar strategi kebudayaan. Konkretnya, membangun sistem pendidikan politik yang menjadikan prinsip kemandirian dan nalar publik sebagai pijakan konseptual, fokus pada penciptaan individu yang otonom dan kritis dalam daya pertimbangan.Untuk mendukung hal tersebut, diperlukan konsep pendidikan dengan menekankan pada proses learning to know, learing to do, learning to be and learning to live together (Jacques Delors et. Al. 1996). Menerapkan empat pilar tersebut dalam proses 
pendidikan politik berarti memungkinkan peserta didik dapat menguasai cara memperoleh pengetahuan, berkesempatan menerapkan pengetahuan yang dipelajarinya, berkesempatan berinteraksi secara aktif dengan sesama sehingga dapat menemukan dirinya (Soedijarto. 2004). Proses strategi pedagogis ini tentu membidik target jangka panjang yang menentukan cerahtidaknya masa depan demokrasi di negeri ini.

Dengan demikian dapat dipahami bahwa peran pendidikan politik sangat diharapkan untuk membentuk karakter dan mental generasi muda untuk dapat melakukan transformasi budaya dalam upaya membina sistem dan kondisi politik yang kondusif. Suatu tuntutan yang pada hakekatnya telah digariskan oleh para pendiri Republik Indonesia yaitu mencerdaskan kehidupan bangsa dan memajukan kebudayaan nasional, dengan mengedepankan budaya dan etika politik yang patut dibanggakan

\section{B. Pendidikan dan Ekonomi}

Jumlah populasi sekolah mencapai seperempat dari jumlah populasi penduduk di dunia, sementara pembiayaan publik untuk pendidikan hanya mencapai $5 \%$ rata-rata PDB dunia. Secara total pada tahun 1992, pembiayaan publik negara-negara berkembang untuk pendidikan hanya mencapai $4,2 \%$ rata-rata PDB dunia (dimana masih ada yang dibawah $2 \%$ PDB) dan negara-negara maju mencapai $5,3 \%$ rata-rata PDB dunia. Bank Dunia memprediksikan pada tahun 2025 kelompok umur penduduk terbesar adalan di bawah 5 tahun (Delors, 1996:163).

Sistem pendidikan harus berkompetisi dengan sektor-sektor lain untuk mendapatkan pembiayaan publik, terkadang menderita karena pilihan kebijakan dalam alokasi anggaran negara. Menurut Komisi Bank Dunia, peranan kunci dari pendidikan terhadap pengembangan sosial, memperlihatkan bahwa sumberdaya untuk penyelenggaraan pendidikan mesti ditingkatkan. Kalau membandingkan alokasi dana pendidikan di negara-negara berkembang dan negara-negara maju, bagian dari PDB untuk pendidikan di negara-negara maju lebih stabil dari tahun ke tahun, sementara di negara-negara berkembang bagian dari PDB tidak pasti. Seharusnya tidak kurang dari $6 \%$ PDB dialokasikan pada pendidikan, bagi negara-negara yang tidak memiliki target. Contoh, ada negara yang mengalokasikan 
dananya terbesar untuk angkatan bersenjatanya karena sedang perang (Delors, Jacques. 1996:165).

Dampak krisis ekonomi berkepanjangan yang terjadi pada Juli 1997 menyebabkan terjadinya penurunan nilai tukar rupiah US dollar yang menimbulkan kenaikan harga barang dan jasa. Kenaikan harga tersebut telah menyebabkan nilai riil alokasi dana yang diterima dari APBN menurun dibandingkan tahun sebelumnya. Ini sangat berdampak terhadap peningkatan mutu pendidikan karena pembiayaan pendidikan makin menurun (Fattah, 2002:79).

Rendahnya

anggaran pendidikan mengakibatkan besarnya biaya satuan pendidikan per siswa (unit cost) menjadi sangat rendah. Meskipun kita mengerti rendahnya anggaran pendidikan disebabkan karena krisis ekonomi dan kekurangan dana pemerintah. Sementara itu, kalau kita melihat kebutuhan biaya untuk peningkatan mutu pendidikan sangatlah besar. Dengan terjadinya krisis ekonomi dan moneter, tingkat kesejahteraan masyarakat atas pendapatan per kapita riil turun. Menurunnya tingkat penghasilan masyarakat tersebut diperparah dengan meningkatnya jumlah pengangguran. Keadaan ini mengakibatkan biaya produksi meningkat dan biaya penyelenggaraan pendidikan menjadi semakin mahal. Pengelolaan pendidikan semakin rumit karena dihadapkan pada jumlah dan pengeluaran pendidikan menjadi semakin rendah. Oleh sebab itu, masalah yang dihadapi sekarang ialah penajaman prioritas agar supaya dana yang tersedia dapat dimanfaatkan seoptimal mungkin untuk meletakkan dasar agenda reformasi pendidikan nasional.

Dalam kerangka pembiayaan sektor pendidikan, pemerintah Indonesia masih memprioritaskan pendidikan dasar dalam pembiayaan pendidikan selama ini. Sama seperti negara-negara lainnya, Indonesia memandang perlunya pendidikan dasar sebagai landasan utama pendidikan masyarakat Indonesia.

Kalau kita melihat alokasi anggaran pendidikan terhadap PDB di negara-negara tetangga kita, Indonesia mengalokasikan dana paling kecil yaitu sekitar 1,4\% PDB lebih kecil dibanding Nigeria yaitu 2,4\% PDB dan hanya setengahnya dari Vietnam. Berikut ini tabel alokasi anggaran pendidikan Indonesia dan negara-negara tetangga. 
Tabel Persentase Anggaran

Pendidikan terhadap PDB

\begin{tabular}{|l|l|c|}
\hline No & Negara & $\begin{array}{l}\text { Persentase } \\
\text { Anggaran }\end{array}$ \\
\hline 1 & Indonesia & 1,4 \\
\hline 2 & Vietnam & 2,8 \\
\hline 3 & Sri Lanka & 3,4 \\
\hline 4 & Filipina & 3,4 \\
\hline 5 & Brunei & 4,4 \\
\hline 6 & Thailand & 5,0 \\
\hline 7 & India & 5,1 \\
\hline 8 & Malaysia & 5,2 \\
\hline 9 & Korea Selatan & 5,3 \\
\hline 10 & Jepang & 7,3 \\
\hline 11 & Nigeria & 2,4 \\
\hline
\end{tabular}

Sumber : World Development

Indicators, 2003. (Soedijarto. 2009:81)

\section{Menurut perhitungan}

Bappenas bersama BPS dan UNDP pada tahun 2004, per siswa SMP perlu dana per tahun sebesar $\mathrm{Rp}$ 2,4 juta dan untuk SD Rp 1,7 juta. Karena itu, untuk pendidikan dasar diperlukan dana Rp 56 triliun. Untuk tahun 2007 hanya Rp 21 triliun yang disediakan. Untuk peserta didik SDSMP sekitar 33 juta peserta didik, berarti unit cost yang disediakan oleh pemerintah hanya Rp 600 ribu, kurang dari sepertiga dana yang diperlukan(Soedijarto. 2009:110)

Menurut the Economist, pada tahun 2005 anggaran belanja penyelenggaraan perguruan tinggi di seluruh dunia mencapai 300 miliar dollar AS atau 1 persen produk ekonomi. Dari 300 miliar itu anggaran perguruan tinggi di AS mencapai 200 miliar dollar AS, dan dari angka itu 100 miliar dari Pemerintah Federal dipergunakan untuk beasiswa bagi mahasiswa berbakat. Pada tahun 2006, unit cost per mahasiswa untuk penyelenggaraan universitas di AS Rp 200 juta, Jepang Rp 108 juta, dan Eropa Rp 81 juta. Untuk perguruan tinggi di Indonesia hanya 0,13 persen dari PDB atau sekitar Rp 6 juta per mahasiswa, yang harusnya minimal $\mathrm{Rp} 20$ juta (Soedijarto. 2009:111)

Berdasarkan data-data yang dikemukakan di atas, kita bisa mengerti mengapa pendidikan di negara-negara maju berkembang dengan pesat dan makin maju karena pembiayaan pendidikan dialokasikan cukup besar dengan rata-rata di atas 5\% PDB dan relatif stabil. Sementara di negara-negara berkembang alokasi dana pendidikan berkisar $2 \%-3 \%$ PDB, Indonesia hanya 1,4\% PDB. Kita tahu bahwa untuk menjadikan pendidikan bermutu dan berdampak nyata pada kehidupan bangsa dan negara memerlukan biaya yang tidak sedikit. Pentingnya pendidikan dalam mencerdaskan kehidupan bangsa perlu benar-benar dimaknai 
oleh pemerintah Indonesia, sehingga menguatkan political will untuk mengalokasikan dana pendidikan dengan sebaik-baiknya sesuai dengan Undang-undang Dasar 1945.

\section{Peran Pendidikan Dalam Pembangunan Ekonomi}

Konsep yang menyatakan investasi pada SDM dapat meningkatkan pertumbuhan ekonomi diawali dari pemikiran Adam Smith dan para pakar ekonomi klasik lain, yang menekankan pentingnya berinvestasi pada ketrampilan manusia. Pada tahu 1960 Schultz (1961) dan Denison (1962) memperlihatkan bahwa pendidikan memberikan kontribusi secara langsung pada pertumbuhan pendapatan nasional melalui peningkatan ketrampilan dan kapasitas produktif tenaga kerja. Penemuan ini membawa arah studi nilai ekonomis pada investasi pendidikan. Dalam mengukur konstribusi pendidikan terhadap pertumbuhan ekonomi Schultz (1961) menggunakan growth accounting approach dan Denison (1962) menggunakan rate of return to human capital. Kedua pendekatan tersebut digunakan untuk mengukur kontribusi pendidikan pada pertumbuhan ekonomi baik negara-negara maju maupun di negara-negara berkembang. Berdasarkan hasil perhitungan tersebut, menurut Denison antara tahun 1930 - 1960, $23 \%$ tingkat pertumbuhan output di AS dikarenakan meningkatnya pendidikan tenaga kerja. Sementara di Kanada mencapai 25\%, Belgia $14 \%$, Inggris $12 \%$, Argentina $16,5 \%$, Malaysia $14,7 \%$, Philipina $10,5 \%$, Ghana $23,4 \%$, Kenya $12,4 \%$ dan Nigeria 16\% (Psacharopoulos, George and Maureen Woodhall. 1985.:16-17). Kalau kita melihat hasil tersebut dapat disimpulkan bahwa meningkatnya pendidikan tenaga kerja dapat meningkatkan pertumbuhan output bagi negaranegara maju maupun di negaranegara berkembang.

Bukti lain yang menunjukkan hubungan antara berbagai aspek SDM dan pertumbuhan ekonomi ditemukan melalui penelitian yang dilakukan oleh Bank Dunia. Berdasarkan hasil penelitian Hicks (1980) menunjukkan bahwa negaranegara dengan tingkat pengembangan SDM tinggi akan mencapai pertumbuhan ekonomi yang lebih cepat. Namun, hubungan ini tidak bersifat linier karena masih banyak faktor lain yang mempengaruhi pertumbuhan ekonomi. Model pengukuran yang disarankan oleh Wheeler (1980) 
untuk mengukur kontribusi pendidikan dan pengembangan SDM lain terhadap pertumbuhan ekonomi adalah model simultan. Dalam model ini yang diukur bukan hanya pengaruhnya secara langsung tetapi juga secara tidak langsung (memisahkan antara sebab dan dampak) (Psacharopoulos, George and Maureen Woodhall. 1985.:20).

Meskipun tidak satupun dalam penelitian ini dapat menunjukkan jenis pendidikan bagaimana yang bisa memberikan dampak paling besar pada produktivitas atau pertumbuhan ekonomi, namun hasil penelitian menunjukkan bahwa pembiayaan pendidikan seharusnya dianggap sebagai investasi yang produktif bukan hanya dianggap sebagai konsumsi. Oleh karena itu, memang perlu dilakukan evaluasi terhadap opportunity cost dari investasi pendidikan dan dibandingkan dengan investasi lain (modal fisik dan infrastruktur sosial). Selain itu, perlu juga dihitung internal efficiency dan eksternal effieciency dari investasi pendidikan untuk menentukan kombinasi investasi pada tingkat pendidikan yang mana (dasar, menengahdan tinggi) (Psacharopoulos, George and Maureen Woodhall. 1985.:23) Ini merupakan tugas para ekonom negara untuk melakukakan analisa dan evaluasi terhadap investasi pendidikan, dengan tidak mengabaikan bukti yang menunjukkan bahwa pendidikan berkontribusi terhadap pertumbungan ekonomi.

Pendidikan bukan hanya dipandang karena dampaknya terhadap pertumbuhan ekonomi tetapi karena perspektif yang lebih luas dari pengembangan SDM. IImu pengetahuan dan pendidikan merupakan kekuatan pendorong utama pembangunan ekonomi (Delors, 1996:69)

Pentingnya pendidikan dalam proses pembangunan bangsa, tidak hanya perlu diperhatikan oleh negara yang sedang berkembang. Negara yang sudah maju pun tetap memandang pendidikan sebagai bagian yang esensial Soedijarto, 2008:82. Belum mapannya sistem ekonomi nasional bukan karena belum adanya lembaga-lembaga ekonomi, tetapi ini terjadi karena berbagai ketentuan pendidikan yang dirancang untuk menyiapkan generasi muda yang memiliki kemampuan, nilai, dan sikap yang diperlukan bagi kehidupan negara dan bangsa tidak diupayakan dalam proses pembelajaran maupun proses sosialisasi di lembagalembaga pendidikan Soedijarto, 2008:92. 
Muncul kesadaran dalam kepemimpinan Indonesia terhadap kebutuhan membangun dayaguna tinggi sumberdaya manusia (high level manpower) sebagai sumberdaya dasar pembangunan ekonomi. Dalam Repelita tahun 1956 - 1960 dan tahun 1961 - 1969 terdapat pernyataan rendahnya ketrampilan di sektor publik dan swasta merupakan salah satu alasan penting rendahnya produktivitas per capita. Kedua Repelita itu merupakan daftar proyek alokasi jumlah investasi yang dipandang sebgai ukuran yang tepat untuk menghasilkan tingkat pertumbuhan ekonomi melalui rasio output modal (Harbison, Frederick and Charles A. Myers. 1965:193194). Menurut Kolonel Suprayogi, sistem pendidikan Indonesia harus ditransfomasikan untuk memenuhi kebutuhan sumberdaya manusia yang ahli(Harbison, Frederick and Charles A. Myers. 1965:195).

$$
\text { Berdasarkan beberapa studi }
$$
yang dilakukan Bank Dunia, menunjukkan bahwa investasi pendidikan sebagai kegiatan inti pengembangan SDM terbukti telah memiliki, sumbangan yang sangat signifikan terhadap tingkat keuntungan ekonomi (MC Machon dan Boediono, 1992). Berdasarkan temuan studi tersebut, bahwa keuntungan ekonomi (rate of return) investasi pendidikan ternyata lebih tinggi daripada investasi fisik dengan perbandingan rata-rata $15,3 \%$ dan $9,1 \%$. Ini berarti bahwa investasi dalam pendidikan merupakan upaya yang menguntungkan, baik secara sosial maupun ekonomis. Namun demikian, kenyataan membuktikan bahwa pemerintah masih harus diyakinkan dan didorong untuk meningkatkan anggaran belanja untuk membiayai pembangunan di bidang pendidikan (Nanang, 2002 :79).

Berdasarkan data-data di
atas, pendidikan mempunyai kontribusi terhadap pembangunan ekonomi. Sumberdaya manusia yang memiliki pendidikan yang baik dan tinggi akan memiliki produktivitas kerja yang tinggi pula, sehingga dalam bekerja (menjadi pegawai atau wirausahawan) akan memberikan hasil yang tinggi juga dan bisa mendatangkan/memberikan devisa bagi negara melalui meningkatnya pertumbuhan ekonomi

\section{Pendidikan dan Sosial Budaya 1. Wawasan budaya dalam pendidikan}

Hakikat budaya di kategorikan dalam dua pendekatan yaitu pendekatan epistimologis dan pendekatan ontology atau 
metafisik.Pendekatan tentang hakikat pendidikan telah melahirkan berbagai jenis teori mengenai apakah sebenarnya pendidikan itu. Pendidikan itu bukan hanya suatu kata benda tetapi juga merupakan suatu proses atau kata kerja. Menurut Edward B. Tylor, "budaya atau peradaban adalah suatu keseluruhan yang kompleks dari pengetahuan, kepercayaan, seni, moral, hukum, adat-istiadat, serta kemampuan-kemampuan dan kebiasaan lainnya yang diperoleh manusia sebagai anggota masyarakat.

Kebudayaan merupakan suatu proses permanusiaan artinya di dalam kehidupan berbudaya terjadi perubahan, perkembangan, motivasi,. Proses pendidik sebagai suatu proses kebudayaan haruslah melihat peserta didik bukan sebagai suatu entity yang terpecah-pecah tetapi sebagai individu yang menyeluruh atau sebagai seorang manusia seutuhnya. Budaya dicapai manusia melalui proses panjang, melalui pendidikan, melalui sosialisasi sehingga diperoleh internalisasi nilai yang menjadikan sesuatu nilai itu menjadi satu dengan dirinya, menjadi cara berfikirnya, menjadi kebiasaannya, menjadi miliknya yang diaktualisasi secara spontan dalam kehidupan nyata.
Wawasan budaya dari pembangunan kita adalah :

1. Dengan budaya manusia membangun masyarakat dan lingkungan;

2. Dengan budaya manusia membangun pendidikan;

3. Pendidikan melalui budaya terjadi secara kontekstual;

4. Pendidikan melalui budaya terjadi melalui proses;

5. Membangun manusia melalui budaya harus melibatkan fisik, akal dan hati;

6. Membangun manusia melalui budaya, maka nilai-nilai budaya itu harus menyatu dengan dirinya manjadi nuansa batinnya, manjadi sikap dan perilakunya serta yang menjadidasar cara berpikirnya;

8. Pembangunan melalui kebudayaan berarti berkelanjutan yang bersifat konvergen

\section{Pendidikan dan Proses transformasi Budaya}

Terjadinya suatu proses transformasi budaya telah diawali oleh para pendiri negara ini dengan menyatakan tekad untuk mencerdaskan kehidupan bangsa dalam Pembukaan UndangUndang Dasar 1945. Mencerdaskan kehidupan bangsa bermakna membawa bangsa Indonesia 
menuju masyarakat modern. Sebagai proses transformasi budaya, pendidikan diartikan sebagai kegiatan pewarisan budaya dari satu generasi ke generasi yang lain. Ada 3 bentuk transformasi yaitu nilai-nilai yang masih cocok diteruskan misalnya nilai-nilai kejujuran. Rasa tanggung jawab dan lain-lain, yang kurang cocok diperbaiki, misalnya tata cara pesta perkawinan, dan yang tidak cocok diganti misalnya pendidikan seks yang dahulu ditabukan diganti dengan pendidikan seks melalui pendidikan formal. Di sini tampak bahwa proses pewarisan budaya tidak semata-mata mengekalkan budaya secara estafet. Pendidikan justru mempunyai tugas menyiapkan peserta didik untuk hari esok.

Pendidikan merupakan proses membudayakan manusia sehingga pendidikan dan budaya tidak dapat dipisahkan. Pendidikan bertujuan membangun totalitas kemampuan manusia, baik sebagai individu maupun anggota masyarakat.Sebagai unsur vital dalam kehidupan manusia yang beradab, kebudayaan mengambil unsur-unsur pembentuknya dari segala ilmu pengetahuan yang dianggap betul-betul vital dan sangat diperlukan dalam menginterpretasi semua yang ada dalam kehidupannya. Hal ini diperlukan sebagai modal dasar untuk dapat berdaptasi dan mempertahankan kelangsungan hidup (survive). Dalam kaitan ini kebudayaan di pandang sebagai nilai-nilai yang diyakini bersama dan terinternalisasi dalam diri individu sehingga terhayati dalam setiap perilaku. Nilai-nilai yang dihayati ataupun ide yang diyakini tersebut bukanlah ciptaan sendiri dari setiap individu yang menghayati dan meyakininya, semuanya itu diperoleh melalui proses belajar. Proses belajar merupakan cara untuk mewariskan nilai-nilai tersebut dari generasi ke generasi. Proses pewarisan tersebut dikenal dengan proses sosialisasi atau enkulturasi (proses pembudayaan).

Untuk membangun manusia melalui budaya maka nilai-nilai budaya itu harus menjadi satu dengan dirinya, untuk itu diperlukan waktu panjang untuk transformasi budaya. Proses transformasi budaya dapat dilakukan dengan cara mengenalkan budaya, memasukkan aspek budaya dalam proses pembelajaran. Kebudayaan merupakan dasar dari praksis pendidikan maka tidak hanya seluruh proses pendidikan berjiwakan kebudayaan nasional saja, tetapi juga seluruh unsur kebudayaan harus diperkenalkan 
dalam proses pendidikan. Progam pendidikan berbudaya dapat diwujudkan secara efektif di dalam system pondok.System pondok merupakan sarana untuk mempersatukan pendidikan ilmu pengetahuan dengan pendidikan budaya budi pekerti serta nilai-nilai budaya lainnya.Pelaksanaan system pondok jjuga dapat berarti mengembangkan kondisi dan suasana kepondokan di dalam praksis pendidikan.Khusus guru system pondok tersebut mungkin merupakan suatu tuntutan. Dengan system tersebut calon pendidikan akan menghayati suatu tuntutan. Dengan system tersebut para calon pendidik akan dapat melaksankan prinsip-prinsip kebudayaan di dalam praksis pendidikan.

Peranan Pendidikan Formal dalam Proses Pembudayaan (enkulturasi).Sekolah atau pendidikan formal adalah salah satu saluran atau media dari proses pembudayaan Media lainnya adalah keluarga dan institusi lainnya yang ada di masyarakat. Dalam konteks inilah pendidikan disebut sebagai proses untuk "memanusiakan manusia" tepatnya "memanusiakan manusia muda" (meminjam istilah Dick Hartoko). Sejalan dengan itu, kalangan antropolog dan ilmuwan sosial lainnya melihat bahwa pendidikan merupakan upaya untuk membudayakan dan mensosialisasikan manusia sebagaimana yang kita kenal dengan proses enkulturasi (pembudayaan) dan sosialisasi (proses membentuk kepribadian dan perilaku seorang anak menjadi anggota masyarakat sehingga anak tersebut diakui keberadaanya oleh masyarakat yang bersangkutan).

Dalam pengertian ini, pendidikan bertujuan membentuk agar manusia dapat menunjukkan perilakunya sebagai makhluk yang berbudaya yang mampu bersosialisasi dalam masyarakatnya dan menyesuaikan diri dengan lingkungan dalam upaya mempertahankan kelangsungan hidup, baik secara pribadi, kelompok, maupun masyarakat secara keseluruhan.

Daoed Joesoef memandang pendidikan sebagai bagian dari kebudayaan karena pendidikan adalah upaya memberikan pengetahuan dasar sebagai bekal hidup.Pengetahuan dasar untuk bekal hidup yang dimaksudkan di sini adalah kebudayaan. Dikatakan demikian karena kehidupan adalah keseluruhan dari keadaan diri kita, totalitas dari apa yang kita lakukan sebagai manusia, yaitu sikap, usaha, dan kerja yang harus dilakukan oleh setiap orang, menetapkan suatu pendirian dalam 
tatanan kehidupan bermasyarakat yang menjadi ciri kehidupan manusia sebagai makhluk biososial.

$\begin{array}{clr}\text { Pendidikan } & \text { adalah upaya } \\ \text { menanamkan } & \text { sikap dan }\end{array}$
keterampilan pada anggota masyarakat agar mereka kelak mampu memainkan peranan sesuai dengan kedudukan dan peran sosial masing-masing dalam masyarakat. Secara tidak langsung, pola ini menjadi proses melestarikan suatu kebudayaan. Sejalan dengan ini, Bertrand Russel mengatakan pendidikan sebagai tatanan sosial kehidupan bermasyarakat yang berbudaya. Melalui pendidikan kita bisa membentuk suatu tatanan kehidupan bermasyarakat yang maju, modern, tentram dan damai berdasarkan nilai-nilai dan norma budaya. Untuk mewujudkan hal tersebut, para penyelenggara pendidikan harus yakin bahwa program dan proses pembelajaran dapat menggiring siswa agar mampu menggunakan segala apa yang telah dimilikinya yang diperoleh selama proses belajar sehingga bermanfaat dalam kehidupan selanjutnya, baik kehidupan secara akademis maupun kehidupan sehari-hari. Jika kita ingin memisahkan pendidikan dari kebudayaan merupakan suatu kebijakan yang merusak kebudayaan sendiri, malahan menghianati keberadaan proses pendidikan sebagai proses pembudayaan.

Nilai-nilai pendidikan ditransmisikan dengan proses-proses "acquiring" melalui "inquiring". Jadi proses pendidikan bukan terjadi secara pasif atau untuk determined tetapi melalui proses interaktif antara pendidikan dan peserta didik. Proses tersebut memungkinkan terjadinya perkembangan budaya melalui kemampuan-kemampuan kreatif yang memungkinkan terjadinya inovasi dan penemuanpenemuan budaya lainnya, serta asimilasi, akulturasi dan seterusnya. Adaketerkaitan dan saling mempengaruhi antara kebudayaan dan pendidikan, artinya bahwa manusia yang berpendidikan adalah sama dengan orang yang berbudaya. Dengan budaya proses pendidikan juga akan lebih mudah karena mempelajari budaya dapat menumbuhkan kesadaran etik, kesusilaan, dan norma hukum. Jadi peserta didik akan lebih mudah menerima karena mereka mempunyai kesadaran untuk mengikuti proses pendidikan dengan tulus tanpa perlu dipaksaan

\section{Hakikat Pendidikan dan Kebudayaan}


Hakikat budaya di kategorikan dalam dua pendekatan yaitu pendekatan epistimologis dan pendekatan ontology atau metafisik.Pendekatan tentang hakikat pendidikan telah melahirkan berbagai jenis teori mengenai apakah sebenarnya pendidikan itu. Pendidikan itu bukan hanya suatu kata benda tetapi juga merupakan suatu proses atau kata kerja. Menurut Edward B. Tylor, "budaya atau peradaban adalah suatu keseluruhan yang kompleks dari pengetahuan, kepercayaan, seni, moral, hukum, adat-istiadat, serta kemampuan-kemampuan dan kebiasaan lainnya yang diperoleh manusia sebagai anggota masyarakat.

Kebudayaan merupakan suatu proses permanusiaan artinya di dalam kehidupan berbudaya terjadi perubahan, perkembangan, motivasi,. Proses pendidik sebagai suatu proses kebudayaan haruslah melihat peserta didik bukan sebagai suatu entity yang terpecah-pecah tetapi sebagai individu yang menyeluruh atau sebagai seorang manusia seutuhnya. Budaya dicapai manusia melalui proses panjang, melalui pendidikan, melalui sosialisasi sehingga diperoleh internalisasi nilai yang menjadikan sesuatu nilai itu menjadi satu dengan dirinya, menjadi cara berfikirnya, menjadi kebiasaannya, menjadi miliknya yang diaktualisasi secara spontan dalam kehidupan nyata.

\section{Pendidikan dan Proses transformasi Budaya}

Pendidikan merupakan

proses membudayakan manusia sehingga pendidikan dan budaya tidak dapat dipisahkan. Pendidikan bertujuan membangun totalitas kemampuan manusia, baik sebagai individu maupun anggota masyarakat.Sebagai unsur vital dalam kehidupan manusia yang beradab, kebudayaan mengambil unsur-unsur pembentuknya dari segala ilmu pengetahuan yang dianggap betul-betul vital dan sangat diperlukan dalam menginterpretasi semua yang ada dalam kehidupannya. Hal ini diperlukan sebagai modal dasar untuk dapat berdaptasi dan mempertahankan kelangsungan hidup (survive). Dalam kaitan ini kebudayaan di pandang sebagai nilai-nilai yang diyakini bersama dan terinternalisasi dalam diri individu sehingga terhayati dalam setiap perilaku. Nilai-nilai yang dihayati ataupun ide yang diyakini tersebut bukanlah ciptaan sendiri dari setiap individu yang menghayati dan meyakininya, semuanya itu diperoleh melalui proses belajar. 
Proses belajar merupakan cara untuk mewariskan nilai-nilai tersebut dari generasi ke generasi. Proses pewarisan tersebut dikenal dengan proses sosialisasi atau enkulturasi (proses pembudayaan).

Untuk membangun manusia melalui budaya maka nilai-nilai budaya itu harus menjadi satu dengan dirinya, untuk itu diperlukan waktu panjang untuk transformasi budaya. Proses transformasi budaya dapat dilakukan dengan cara mengenalkan budaya, memasukkan aspek budaya dalam proses pembelajaran. Kebudayaan merupakan dasar dari praksis pendidikan maka tidak hanya seluruh proses pendidikan berjiwakan kebudayaan nasional saja, tetapi juga seluruh unsur kebudayaan harus diperkenalkan dalam proses pendidikan. Progam pendidikan berbudaya dapat diwujudkan secara efektif di dalam sistem pondok.Sistem pondok merupakan sarana untuk mempersatukan pendidikan ilmu pengetahuan dengan pendidikan budaya budi pekerti serta nilai-nilai budaya lainnya.Pelaksanaan system pondok juga dapat berarti mengembangkan kondisi dan suasana kepondokan di dalam praksis pendidikan.Khusus guru system pondok tersebut mungkin merupakan suatu tuntutan. Dengan system tersebut calon pendidikan akan menghayati suatu tuntutan. Dengan system tersebut para calon pendidik akan dapat melaksankan prinsip-prinsip kebudayaan di dalam praksis pendidikan.

Peranan Pendidikan Formal dalam Proses Pembudayaan (enkulturasi).

Sekolah atau pendidikan formal adalah upaya membentuk perilaku dan sikap seseorang yang didasari oleh ilmu pengetahuan, keterampilan sehingga setiap individu dapat memainkan perannya masing-masing. Dengan demikian, ukuran keberhasilan pembelajaran dalam konsep enkulturasi adalah perubahan perilaku siswa. Hal ini sejalan dengan 4 (empat) pilar pendidikan yang dikemukakan oleh Unesco, Belajar bukan hanya untuk tahu (to know), tetapi juga menggiring siswa untuk dapat mengaplikasikan pengetahuan yang diperoleh secara langsung dalam kehidupan nyata (to do), belajar untuk membangun jati diri (to be), dan membentuk sikap hidup dalam kebersamaan yang harmoni (to live together ). Media lainnya adalah keluarga dan institusi lainnya yang ada di masyarakat. Dalam konteks inilah pendidikan disebut sebagai proses untuk "memanusiakan manusia" tepatnya "memanusiakan manusia muda" (meminjam istilah 
Dick Hartoko). Sejalan dengan itu, kalangan antropolog dan ilmuwan sosial lainnya melihat bahwa pendidikan merupakan upaya untuk membudayakan dan mensosialisasikan manusia sebagaimana yang kita kenal dengan proses enkulturasi (pembudayaan) dan sosialisasi (proses membentuk kepribadian dan perilaku seorang anak menjadi anggota masyarakat sehingga anak tersebut diakui keberadaanya oleh masyarakat yang bersangkutan). Dalam pengertian ini, pendidikan bertujuan membentuk agar manusia dapat menunjukkan perilakunya sebagai makhluk yang berbudaya yang mampu bersosialisasi dalam masyarakatnya dan menyesuaikan diri dengan lingkungan dalam upaya mempertahankan kelangsungan hidup, baik secara pribadi, kelompok, maupun masyarakat secara keseluruhan.

Daoed Joesoef memandang pendidikan sebagai bagian dari kebudayaan karena pendidikan adalah upaya memberikan pengetahuan dasar sebagai bekal hidup.Pengetahuan dasar untuk bekal hidup yang dimaksudkan di sini adalah kebudayaan. Dikatakan demikian karena kehidupan adalah keseluruhan dari keadaan diri kita, totalitas dari apa yang kita lakukan sebagai manusia, yaitu sikap, usaha, dan kerja yang harus dilakukan oleh setiap orang, menetapkan suatu pendirian dalam tatanan kehidupan bermasyarakat yang menjadi ciri kehidupan manusia sebagai makhluk biososial.Pendidikan sebagai upaya menanamkan sikap dan keterampilan pada anggota masyarakat agar mereka kelak mampu memainkan peranan sesuai dengan kedudukan dan peran sosial masing-masing dalam masyarakat. Secara tidak langsung, pola ini menjadi proses melestarikan suatu kebudayaan. Sejalan dengan ini, Bertrand Russel mengatakan pendidikan sebagai tatanan sosial kehidupan bermasyarakat yang berbudaya.

Melalui pendidikan kita bisa membentuk suatu tatanan kehidupan bermasyarakat yang maju, modern, tentram dan damai berdasarkan nilai-nilai dan norma budaya. Untuk mewujudkan hal tersebut, para penyelenggara pendidikan harus yakin bahwa program dan proses pembelajaran dapat menggiring siswa agar mampu menggunakan segala apa yang telah dimilikinya yang diperoleh selama proses belajar sehingga bermanfaat dalam kehidupan selanjutnya, baik kehidupan secara akademis maupun kehidupan sehari-hari. Jika 
kita ingin memisahkan pendidikan dari kebudayaan merupakan suatu kebijakan yang merusak kebudayaan sendiri, malahan menghianati keberadaan proses pendidikan sebagai proses pembudayaan.

Nilai-nilai pendidikan ditransmisikan dengan prosesproses "acquiring" melalui "inquiring". Jadi proses pendidikan bukan terjadi secara pasif atau untuk determined tetapi melalui proses interaktif antara pendidikan dan peserta didik. Proses tersebut memungkinkan terjadinya perkembangan budaya melalui kemampuan-kemampuan kreatif yang memungkinkan terjadinya inovasi dan penemuan-penemuan budaya lainnya, serta asimilasi, akulturasi dan seterusnya. Dengan budaya proses pendidikan juga akan lebih mudah karena mempelajari budaya dapat menumbuhkan kesadaran etik, kesusialaan, dan norma hukum. Jadi peserta didik akan lebih mudah menerima karena mereka mempunyai kesadaran untuk mengikuti proses pendidikan dengan tulus tanpa perlu dipaksaan.

\section{KESIMPULAN}

Bahwa kondisi real politik dan politik pendidikan di Indonesia belum sepenuhnya merdeka dan tertinggal dari tuntutan daya saing global, belum mampu memberikan harapan konkrit atas kemajuan bangsa di masa depan. Karena itu pendidikan politik diharapkan mampu membentuk karakter dan mental generasi muda agar dapat melakukan transformasi budaya dalam upaya membina sistem dan kondisi politik yang kondusif dengan mengedepankan budaya dan etika politik yang patut dibanggakan.Budaya politik tidak dapat dipisahkan dengan etika politik, karena tidak santunnya budaya politik membutuhkan legitimasi yang merujuk pada norma moral, nilai hukum atau peraturan perundangan. Karena itu untuk membangun kondisi politik yang kondusif, diperlukan politisi yang memahami dan mampu mengamalkan budaya dan etika politik yang positif, yang mana hal tersebut dapat diperoleh melalui pendidikan politik yang dilakukan sejak dini.Pendidikan ini salah satunya dapat dilakukan di keluarga, partai politik dan sekolah melalui civic education.

Selanjutnyadalam investasi SDM ada kaitan antara pendidikan, produktivitas kerja, dan pertumbuhan ekonomi. Pendidikan hendaknya dipandang bukan hanya karena dampaknya terhadap pertumbuhan ekonomi tetapi karena 
perspektif yang lebih luas dari pengembangan SDM. IImu pengetahuan dan pendidikan merupakan kekuatan pendorong utama pembangunan ekonomi. Oleh karena itu, investasi pendidikan mestinya dilakukan dengan serius dan alokasi dana untuk pendidikan benar-benar dipenuhi mengingat pentingnya pendidikan dalam mencerdaskan kehidupan bangsa.

Namun demikian, kenyataan membuktikan bahwa pemerintah masih harus diyakinkan dan didorong untuk meningkatkan anggaran belanja untuk membiayai pembangunan di bidang pendidikan.

Bahwa kondisi sosial budaya yang terjadi saat ini turut menentukan arah pendidikan yang dilakukan.Namun, demikian lembaga pendidikan diharapkan tidak hanyut dalam arus perubahan yang kadang sangat bertentangan dengan nilai-nilai kebajikan. Budaya yang kuat adalah budaya yang mampu mempertahankan entitasnya dan tidak parsial sehingga akan terus dijadikan pegangan bagi masyarakat penganutnya dan bahkan dapat dijadikan sandaran bagi tumbuhnya potensi-potensi baru demi menjaga tetap terpatrinya budaya itu.

Pendidikan merupakan salah satu wadah yang dapat secara maksimal digunakan sebagai ajang penggemblengan karakter dan nilainilai kesejatian.Sebagai ajang pembudayaan.Pendidikan menjadi instrumen kekuatan sosial masyarakat untuk mengembangkan suatu sistem pembinaan yang relevan dengan tuntutan perubahan zaman.Untuk itu, pendidikan hendaknya mampu melakukan fungsinya, melakukan tugas-tugas kelembagaan sesuai dengan hukum perkembangan masyarakat.Dalam hal ini, pendidikan hendaknya memperhatikan benar modal kutlural dan modal sosial di samping modal-modal dasar lainnya.

Pendidikan sejatinya harus berperan maksimal dalam mengembangkan kebudayaan nasional.Untuk itu diperlukan transformasi pedagogik yang direncanakan, dilaksanakan dan dikontrol dengan baik. Hal-hal yang dapat dilakukan misalnya mengembangkan civic intelligent yang termasuk di dalamnya pendidikan multikultural dan pendidikan karakterpada lembaga pendidikan yang menerapkan community based education. Dalam konsep ini diharapkan akan diperoleh masyarakat madani (civic society) yang memahami dengan baik hak-haknya dengan menunaikan kewajibankewajibannya demi kemaslahatan bangsa dan negara. Selain itu, 
penidikan multicultural dan pendidikan karakter juga perlu dilaksanakan.

\section{DAFTAR PUSTAKA}

Arifin, Anwar. http://www.lfip.org/ english/pdf/bali-seminar/ Sisdiknas

Buchori, Mochtar., 2000. Peranan Pendidikan dalam Pembentukan Budaya Politik di Indonesia.Yogyakarta.Kanisi us.

Budiarjo, Mariam., 1997. DasarDasar IImu Politik. Jakarta. Gramedia.

Delors, Jacques et.al, 1996, Learning: The Treasure Within, The Report to UNESCO of International Commission for The TwentyFirst Century, Paris: UNESCO.

Dewey, John., 1961. Democracy and Education: Introduction to the Philosophy of Education. New York. Mac Millan Company.

Fattah, Nanang. 2002. Ekonomi \& Pembiayaan Pendidikan. Bandung : Remaja Rosdakarya.

Freire, Paulo., 1970. The Real Meaning of Cultural Action.Aktie.Comitee.
Harbison, Frederick and Charles A. Myers. 1965. Manpower and Education. USA : McGraw Hill Book Company.

Kartono, Kartini., 1989. Pendidikan Politik sebagai Bagian dari Pendidikan Orang Dewasa. Bandung. Mandar Maju.

Kartono, Kartini., 1990. Wawasan Politik: Mengenai Sistem Pendidikan Nasional. Bandung. Mandar Maju.

Psacharopoulos, George and Maureen Woodhall. 1985. Education for Development, An Analysis of Investment Choices. USA : A World Bank Publication.

Soedijarto. Kurikulum, Sistem Evaluasi dan Tenaga Kependidikan Sebagai Unsur Strategis,.Makalah.Jurnal Pendidikan PenaburNo.03/Th.II//Desember 2004. Soedijarto, 2008, Landasan dan Arah Pendidikan Nasional Kita, Jakarta:PT.Kompas Media Nusantara.

Tilaar., 2003. Kekuasaan dan Pendidikan: Manajemen Pendidikan Nasional dalam Pusaran Kekuasaan. Jakarta. Rineka Cipta.

Zamroni, 2002, Paradigma Pembangunan Pendidikan Nasional Dalam Mewujudkan Peradaban Bangsa, dalam 
buku Pendidikan Untuk

Masyarakat Indonesia Baru:

70 Tahun Prof. Dr. H.A.R.
Tilaar, M.Sc. Jakarta:

Grasindo. 